\title{
Development Model of Professionalism Guidance and Counseling Teacher
}

\author{
Dwi Yuwono Puji Sugiharto, Achmad Rifai, Suripto \\ Universitas Negeri Semarang, Semarang, Indonesia \\ e-mail: dypsugiharto@mail.unnes.ac.id
}

\begin{abstract}
Developing professionalism teacher today prefer to conventional and suspected that there's not really effective yet, such as inappropriate training toward individual necessary by the teacher, teacher teamwork activity limited themself for attending and do something else. The aims of this study to (1) analyzing the necessary of developing professionalism teacher, (2) improving the design of professionalism teacher based on Self-regulated learning, (3) Testing the properness of the developing professionalism teacher based on Self-regulated learning. The study was R\&D (Research and Development). This study consist of four stages: literature study, preface study, development and evaluation stage. The result of this research showed that the necessary of developing professionalism teacher absolutely high. The design model development was improved by Self-regulated learning model, the properness of Self-regulated learning model was tested by the experts who declared that Self-regulated learning appropriate to be experimented. The benefits of this research as the study of science in guidance and counseling, in addition widen more knowledge about the appropriate development model.
\end{abstract}

Keywords: Guidance, Counseling, Professionalism, Development, Teacher

\section{INTRODUCTION}

Education is a very important field for human life in a nation, education can build the future of a nation by encouraging the improvement of the quality of human resources (HR) by doing increased competence cognitive, affective, and psychomotor through formal education, non-formal and informal. In order to achieve the goals of national education, i.e., develop the intellectual life of whole person, it takes the role of a professional educator. Haryono, et.all. (2017) told that: "To prepare the student to be a member of the global community should effectively improve their self to gain a high chance to participate and build their self-existence facing the global community challenges"

Education aims are prepare students in the development of global needs to already for self-build self-existence challenges of the current global. Therefore, the professionalism of teachers required to evolving in accordance with the changing times, science, technology and the needs of the community including the needs of the human resources (HR) quality. One way of developing the teacher professionalism is through the training program. A training program that expected an effort by provide the knowledge and insight into a variety of learning innovations is a concept or practice by framework of increasing the professionalism of teachers and students ' learning results acquisition. (Haryono, et.al. 2017).

Training programs can using any effort in developing the profession. The professional development efforts shows a broad effort to increasing learning organizational performance. According to Gaff (1975) and Doughty (2006), there are three inter-related efforts, i.e instructional development, development organizations, professional development. Teachers as educators is the deciding factor of success of education in schools.

The teacher duty is providing knowledge (cognitive), attitudes/values (affective), and skill (psychometer) to students. Teachers Professionalism 
must be divided into three competencies, i.e: (1) cognitive competence, i.e. the ability in the field of intellectual property (2) affective Competencies, i.e. the readiness and ability of teachers in a wide range of matters relating to his duty of profession, (3) behavioural competencies, i.e. the ability to behave.

Sustainable Development Professionalism is a guide to continuous learning for teachers as the main line to bring about the changes that related to student success. Thus, it is expected students to have more knowledge, better skills, and a deep understanding of teaching material as well as capable of demonstrating what they know and are able to do so. Sustainabel Development Professionalism includes various ways or approach in which teachers are continually learning after obtaining an education or training as a teacher.

Based on these problems a system needs solutions that can provide Professionalism teachers develop continuously according to requirements and ability of teachers. One of the systems that can provide the solution is the existence of the construction professionalism teachers model.

\section{METHOD}

This research is a research and development. Early research needs of teachers began with the identification of the requirements of development guidance and counseling teacher's in semarang Indonesia. Data analysis techniques usedis reduction, followed by evaluation experts and test effectiveness refers to the hypothetical model developed. Development process model passed the test stage public to target professional teachers.

\section{RESULT AND DISCUSSION}

\subsection{Requirements analysis model of modern Guidance and Counseling teacher-based on Self-regulated learning}

This research was carried out with the phase beginning i.e. assessment of need or needs analysis performed through the FGD (focus group discussion) by inviting guidance and counseling teachers in Central Java, which is represented by 5 teacher. The result of the initial teacher needs to generate guidance and counseling FGD then made the initial design models.

Based on FGD executed note that guidance group has carried out more than $50 \%$ by the respondents, but not yet fully implemented in each institution. Program execution of counseling by guidance and counseling teacher was implemented, even though not yet fully implementing it with guidance and counseling teacher comparison 30:50. With existence of this condition, it needs supplements and treatments in order to manifest implement of program.

Group guidance service program at school requires an evaluation to know implementation levels of the program. This is doing in addition not only to know levels of rate but also quality of the activities implementation of counselling activity, in FGD there are some places that no group counseling activities programmed. It is build into a reference for the models in process to develop about the needs of the program implementation.

Counselling activities can be yardsticks in guidance and counselling teacher readiness to build multi service of guidance and counselling in schools, but in reality only $60 \%$ that have been carrying out this activities. It is also revealed that wide schools had been implementing but not yet all teacher in school of guidance and counselling want to implement. Based on FGD results than made professionalism guidance and counselling model development based self-regulated learning.

\subsection{Develop the design of model- development teacher professionalism based self-regulated learning}

The design of instrument development model profesionalism-based self-regulated learning for guidance counseling teacher consisting of modernity, guidance and counseling teacher perception, and the improvement of quality guidance and counselling services in schools.

The design of early models derived from needs analysis by following the syntax model:

The design of early models derived from needs analysis by following the syntax model:

Development Model of modern guidance and counselling teachers is divided into two phases, i.e performance phase and reflection phase. Performance and relfection phase consists on elements of motivation, strategy, potential and modernisation that become an important aspect in the process of self-regulated learning. In this phase, Indicator of achievement in every aspect was finished by the teacher through the ability of teachers in self-evaluation. This capability is 
measure to ability of yourself in the process of lifelong learning.

The future phase is called next phase, this means the hope of improved models. This phase is identifies teachers from professional and modernity who have been using this model. In accordance with the research objectives, the purpose of this model is to bring modern habits into social transform ability as a professional and it able to build the best multi service guidance and counselling at school.

\subsection{The feasibility of the of modern guidance and Counseling teacher's model-based self-regulated learning}

The feasibility of this modern guidance and counselling models is feasibility through expert judgement, including scientific experts and theories of learning. The results of the eligibility test on the application of the model, the feasibility of components, and the application of the obtained results it deserves. Then in a twofold prediction model reinforces the appropriateness, researchers conduct feedback and reflection the colleague friend get the results deserve to be implemented.

Based on the research and development that has been done. It was doing with the final step of a feasibility test, then the modern teacher's Guidance and counselling model deserves to be applied in order to improve professionalism and modernity teacher Guidance and counseling. This is in accordance with the statement of Utanto, et.al (2016) stating that "the implications of the research development of this model, the next researcher is expected to be able to use the guideline of the development model based on the research that has already been conducted to be developed on other subjects."

In this study, teacher professionalism mentoring model developed based on Self-regulated learning (Zimmerman, 2002, 1989). Self-regulated learning selected to handle teachers in developing professionalism based on four reasons.

First, the Self-regulated learning places emphasis on lifelong learning (Smith, 2001). Lifelong learning is very important as the main capital stressed the teacher to be survive and adapt in the future filled with uncertainty (Dryden \& Vos, 1999; Handy, 1997).

Second, Self-regulated learning is a collaboration between motivation, strategies and potential teachers in learning (Zimmerman, 1989).
In handling potential teachers comprehensive professionalism it can handling through collaboration of motivation, strategy and expected increase.

Third, Self-regulated learning is not a potential (such as intelligence) but rather a strategy and process (Zimmerman, 2002) because of it's Selfregulated learning can be applied by teacher triuble in study with the level of potential study of high or low and in a wide range of talents and interests.

Lastly, Self-regulated learning was able to give a specific description of the various components that affect the success of the Excel. Various research results show that Self-regulated learning effect on achievement (Ablart \& Lipschultz, 1998; Chen, 2002; Schunk \& Ertmer, 1999; Sunawan, 2004; Zimmerman \& Martinez-Pons, 1988, 1990).

\section{CONCLUSION}

Needs analysis for guidance and counseling stated still lacking aspects of developing skills for teachers, it was decided that further education teachers be more effective through adoption of a method of self-regulated learning. Develop design model-based development of teacher professionalism self-regulated learning begins with the design of syntax and create guidelines implementation model. Feasibility test of modelbased development of teachers of modern guidance and counseling self-regulated learning done expert fields were declared eligible for experimented.

\section{REFERENCES}

[1] Adler, P.A., \& Adler, P. 1994. Observational Technique. Dalam N.K. Denzin \& Y.S. Lincoln (ed.). Handbook of Qualitative Research. Thousand Oaks: SAGE Publications.

[2] Chen, C.S. 2002. Self-regulated Learning Strategies and Achievement in an Introduction to Information System Course. Information Technology, Learning, and Performace Journal, 20 (1), 11-25.

[3] Dryden, G., \& Vos, J. 1999. The Learning Revolution: To Change the Way the World Learns. Diterjemahkan Baiquni, A. Bandung; Penerbit Kaifa.

[4] Handy, C. 1997. Menemukan Makna dalam Ketidakpastian. Gibson, R (ed). Rethinking the Future. Diterjemahkan Brata, dkk. Jakarta: PT Gramedia.

[5] Haryono, H., Stanislaus, S., Budiyono, B., \& Widhanarto, G. (2017). Peningkatan Profesionalisme Guru melalui Pelatihan Inovasi Pembelajaran: Program Rintisan bagi Guru di Kabupaten Semarang. Lembaran Ilmu 
Kependidikan, 46(2), 75-80. Retrieved from https://journal.unnes.ac.id/nju/index.php/LIK/art icle/view/12031

[6] Smith, P.A. 2001. Understanding Self-regulated Learning and Its Implications for Accounting Educators and Research. Issues in Accaunting Education, 16 (4), 663-667.

[7] Schunk, D.H., \& Ertmer, P.A. 1999. Self Regulatory Process During Computers Skill Acquisition: Goal and Self Evaluative Influence. Journal of Educational Psychology, 91 (2), 251-260.

[8] Sunawan, 2004. Pengaruh Penggunaan Strategi Pengelolaan Diri dalam Belajar terhadap Prestasi Belajar Matematika Siswa Sekolah Menengah Umum (SMU). Jurnal Pendidikan, $10(1), 92-114$.

[9] Yuli Utanto, Ghanis Putra Widhanarto, and Yoris Adi Maretta. (2017); A web-based portfolio model as the students' final assignment: Dealing with the development of higher education trend. AIP Conference Proceedings 1818, 020063; doi: 10.1063/1.4976927

[10] Zimmerman, B.J. 2002. Becoming A Selfregulated Learner: An Overview. Theory into Practice. (Diakses melalui Www.findarticles.com pada tanggal 14 Nopember 2006).

[11] Zimmerman, B.J. 1989. A Social Cognitive View of Self-regulated Academic Learning. Journal of Educational Psychology, 81 (3), 329. 339.

[12] Zimmerman, B.J., \& Martinez-Pons, M. 1990. Students Defferences in Self-regulated Learning: Relating Grade, Sex, and Giftedness to Self Efficacy and Strategy Use. Journal of Educational Psychology, 82 (1), 51-59.

[13] Zimmerman, B.J., \& Martinez-Pons, M. 1988. Construct Validation of Strategy Model of Student Self-regulated Learning. Journal of Educational Psychology, 80 (2), 284-290. 